Підпала Т. В., доктор сільськогосподарських наук,

Зайцев $\epsilon$. М.,

Правда А. О.

Миколаївський національний аграрний університет

\title{
РЕЗУЛЬТАТИ ВИКОРИСТАННЯ БУГАЇВ-ПЛІДНИКІВ ГОЛШТИНСЬКОЇ ПОРОДИ ПРИ СТВОРЕННІ ВИСОКОПРОДУКТИВНОГО СТАДА
}

\author{
Рецензент - доктор сільськогосподарських наук С. І. Луговий
}

\begin{abstract}
Мета статmi - оцінити прояв господарсько корисних ознак у корів-дочок різних бугаїв-плідників голитинської породи.

Методика дослідження. У прочесі дослідження використані загальноприйняті зоотехнічні методи (індивідуальний облік молочної продуктивності, відтворювальної здатності), лабораторні (визначення якісного складу молока), ретроспективний аналіз (показники за весь період використання тварин), варіачійно-статистичний метод (визначення параметрів ознак).

Результати дослідження. У результаті вивчення використання бугаїв-плідників голштинської породи при створенні високопродуктивного стада молочної худоби з'ясовано, щео на рівень розвитку продуктивних, відтворювальних $і$ адаптивних властивостей корів-дочок впливає походження за батьком. Встановлено взаємозв'язок між господарсько корисними ознаками корів первісток голштинської породи німеиької та украӥнської селекиії, які походять від різних бугаїв. Незалежно від походження піддослідних тварин зберігається позитивна високого ступеня корелячія між надоєм $і$ кількістю молочного жиру та білка. Загальною закономірністю для потомства бугаїв голитинської породи є наявність позитивної корелячії низького, середнього і високого ступенів між надоєм і тривалістю сервіс-періоду. Визначено відмінності за напрямом і ступенем кореляційної залежності між продуктивними і відтворювальними ознаками у корів-первісток, які й характеризують різноманітність впливу бугаїв на їхніх дочок.
\end{abstract}

Елементи наукової новизни. Набули подальшого розвитку теоретичні та практичні положення щодо підвищення продуктивності тварин та створення високопродуктивних стад молочної худоби за використання генофонду голитинської породи.

Практична значущість. Одержані результати потрібно враховувати у прочесі поліпшуючої селекиії під час формування високопродуктивного стада молочної худоби голитинської породи.

Ключові слова: голитинська порода, покоління, молочна продуктивність, відтворювальна здатність, індекс адаптачії, кореляція.

Підпала Тетяна Василівна - доктор сільськогосподарських наук, професор, завідувач кафедри технології переробки, стандартизації і сертифікації продукції тваринництва, Миколаївський національний аграрний університет, вул. Г. Гонгадзе, 9, м. Миколаїв, 54020, Україна, e-mail: pidpala@mnau.edu.ua, ORCID ID: 0000-0002-4072-7576.

Зайцев Євген Миколайович - здобувач вищої освіти ступеня доктора філософії кафедри технології переробки, стандартизації і сертифікації продукції тваринництва, Миколаївський національний аграрний університет, вул. Г. Гонгадзе, 9, м. Миколаїв, 54020, Україна, e-mail: zaitsev_yevhen@ukr.net, ORCID ID: 0000-0002-4165-4196.

Правда Анастасія Олександрівна - магістр кафедри технології переробки, стандартизації і сертифікації продукції тваринництва, Миколаївський національний аграрний університет, вул. Г. Гонгадзе, 9, м. Миколаїв, 54020, Україна, e-mail: pravdanasta3@gmail.com.

Постановка проблеми. У генетичному поліпшенні молочних порід великої рогатої худоби важливу роль відіграє спадковість бугаїв-плідників. Про це свідчить підвищення рівня продуктивності, поліпшення екстер'єрних і технологічних властивостей у тварин. Найбільшим попитом користуються плідники голштинської породи. Їх використання для осіменіння маточного поголів'я за методом вбирного схрещування сприяє збільшенню генетичного потенціалу і є однією з основних складових формування високопродуктивного стада молочної худоби [14]. Це найбільш надійний метод швидкого створення консолідованих за типом будови тіла, рівнем продуктивності та тривалістю господарського використання високопродуктивних молочних стад. Інтенсивне застосування генофонду голштин- 


\section{СІЛЬСЬКЕ ГОСПОДАРСТВО. ТВАРИННИЦТВО}

ської породи для удосконалення вітчизняних порід молочної худоби, виведення нових порід та створення високопродуктивних стад сприяє прискоренню селекційного процесу. Тому дослідження результативності використання бугаїв-плідників голштинської породи при формуванні високопродуктивних стад $є$ актуальним.

Аналіз останніх досліджень і публікацій, у яких започатковано розв'язання проблеми. Про високий генетичний потенціал продуктивності бугаїв-плідників і доцільність їх інтенсивного використання за принципом відкритої популяції повідомляють учені [7, 8, 10]. Порівняльною характеристикою продуктивності матерів та їх дочок встановлено більший вплив на ознаки дочок батьків, ніж матерів $[2,5]$. Бугаї голштинської породи значно підвищують рівень молочності у їх дочок, але при певному зниженні відтворювальної здатності, що свідчить про порушення у них пристосованості до умов середовища [9]. На основі поглинального схрещування маток червоної степової худоби з бугаямиплідниками червоно-рябої голштинської породи створюється репродуктор голштинської худоби [13]. Основним напрямом створення високопродуктивних стад молдавського типу чорно-рябої худоби $\epsilon$ схрещування чорно-рябої, червоної степової та симентальської порід із бугаями голштинської породи [5].

У конкретному стаді ефективність селекційного процесу значною мірою зумовлена використанням тварин, родоводи яких насичені предками 3 високими племінними якостями. Для створення стада інтенсивного молочного типу на маточному поголів ї бажано використовувати бугаїв-плідників голштинської породи, жіночим предкам яких притаманні високі надої, вміст жиру і білка в молоці та міцність конституції $[3,4]$. Саме бугаям-плідникам належить провідна роль у створенні високопродуктивної популяції голштинської худоби [1].

Поряд із зазначеним, важливим є постійна й об'єктивна оцінка результатів використання бугаївплідників голштинської породи і контроль за змінами, які відбуваються при цьому у стаді молочної худоби.

Мета досліджень - оцінити прояв господарськи корисних ознак у корів-дочок різних бугаївплідників голштинської породи.

Зазначену мету досягнуто через такі завдання: визначити розвиток продуктивних, відтворювальних та адаптаційних ознак у корів-дочок різних бугаїв-плідників голштинської породи; встановити прояв селекційних ознак у корів-дочок, що похо- дять від різних батьків у суміжних поколіннях; оцінити реалізацію спадковості голштинської породи німецької та української селекції за продуктивністю корів-первісток, що походять від різних батьків.

Матеріали і методи досліджень. Дослідження 3 оцінки ефективності використання бугаїв-плідників голштинської породи при створенні високопродуктивного стада проводили у племінному заводі СТОВ «Промінь» Арбузинського району Миколаївської області. Господарство є лідером молочного бізнесу в Україні. Висока ефективність молочного скотарства зумовлена впровадженням інноваційних технологічних рішень виробництва молока на промисловій основі у поєднанні 3 досконалими системами управління. Це сприяло прояву генетичного потенціалу тварин голштинської породи. Середній надій на одну корову в 2017 році становив 11069 кг молока.

Матеріалом для досліджень слугували дані по 712 коровам-первісткам голштинської породи двох суміжних поколінь, 3 них 362 тварини німецької селекції та 350 - української селекції. Розвиток ознак у дочок різних бугаїв-плідників оцінювали за надоєм, вмістом жиру і білка в молоці, кількістю молочного жиру і білка, кількістю молочного жиру за добу $[6,12]$ як за 305 днів, так і за всі дні першої лактації. Одержані результати досліджень опрацьовано за допомогою варіаційно-статистичних методів $[11,12]$ і пакету програмного забезпечення MS Office Excel 2010.

Результати досліджень та їх обговорення. Встановлено різний рівень розвитку господарски корисних ознак у корів голштинської породи німецької селекції, що відрізняються походженням за батьком. Серед первісток I генетико-екологічного покоління (ГЕП) кращими за надоєм були дочки бугаїв Джеферсона 347023457, Лаудана 578448776, Альвеса 255206543 і Джуруса 768076721. Вони переважали ровесниць - дочок плідника Судана 343015244, відповідно на 1561 кг, 1524 кг, 1197 кг і 668 кг (табл. 1). Проте у наступному поколінні (II ГЕП) продуктивність потомства бугая Лаудана 578448776 була нижчою, ніж дочок інших батьків.

Серед досліджуваного поголів'я первісток II ГЕП кращими були дочки бугаїв Дензеля 101431985, Гівенчі 128226159, Луціо 578448776 і Тандема 9434213. Різниця за величиною надою за лактацію порівняно 3 ровесницями, батьком яких був плідник Лаудан 578448776, відповідно, становила 1971 кг (Р>0,95), 1276 кг, 564 кг і 522 кг молока (табл. 2). 
СІЛЬСЬКЕ ГОСПОДАРСТВО. ТВАРИННИЦТВО

\section{1. Характеристика за господарсько корисними ознаками корів голштинськой породи} німецької селекції, що походять від різних плідників (I ГЕП, матері), $\bar{X} \pm S x$

\begin{tabular}{|c|c|c|c|c|c|}
\hline \multirow[b]{2}{*}{ Ознака } & \multicolumn{5}{|c|}{ Кличка бугая, інв. №, лінія } \\
\hline & 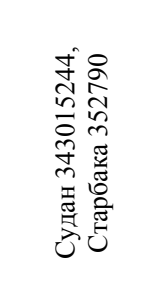 & 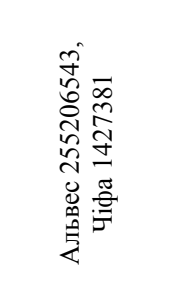 & 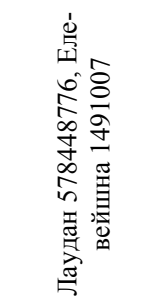 & 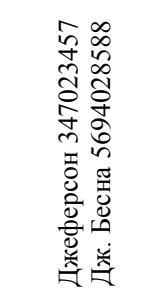 & 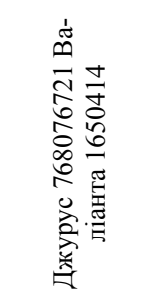 \\
\hline Враховано тварин, голів & 7 & 5 & 5 & 9 & 8 \\
\hline Тривалість лактації, днів & $310,7 \pm 9,14$ & $298,8 \pm 13,73$ & $323,4 \pm 13,46$ & $346,2 \pm 36,13$ & $340,5 \pm 31,19$ \\
\hline Надій за лактацію, кг & $8533 \pm 505,0$ & $9730 \pm 605,6$ & $10057 \pm 748,3$ & $10094 \pm 876,4$ & $9201 \pm 572,1$ \\
\hline Надій за 305 днів лактації, кг & $8340 \pm 495,1$ & $9730 \pm 355,3^{*}$ & $9639 \pm 523,0$ & $8684 \pm 222,5$ & $8372 \pm 532,1$ \\
\hline Вміст жиру в молоці, \% & $3,86 \pm 0,041$ & $3,94 \pm 0,022$ & $3,90 \pm 0,010$ & $3,92 \pm 0,054$ & $3,94 \pm 0,084$ \\
\hline Кількість молочного жиру, кг & $322,0 \pm 19,22$ & $373,8 \pm 13,98$ & $375,6 \pm 19,83$ & $340,8 \pm 10,87$ & $329,8 \pm 20,25$ \\
\hline Вміст білка в молоці, \% & $3,18 \pm 0,022$ & $3,19 \pm 0,029$ & $3,20 \pm 0,025$ & $3,18 \pm 0,019$ & $3,19 \pm 0,018$ \\
\hline Кількість молочного білка, кг & $265,7 \pm 16,07$ & $303,6 \pm 12,92$ & $307,8 \pm 15,62$ & $275,8 \pm 6,93$ & $267,2 \pm 16,80$ \\
\hline Кількість молочного жиру за добу, кг & $1,06 \pm 0,064$ & $1,28 \pm 0,028^{* *}$ & $1,20 \pm 0,051$ & $1,16 \pm 0,036$ & $1,08 \pm 0,054$ \\
\hline $\begin{array}{l}\text { Тривалість } \\
\text { сервіс-періоду, днів }\end{array}$ & $89,1 \pm 8,64$ & $67,8 \pm 15,74$ & $100,2 \pm 11,99$ & $124,5 \pm 36,34$ & $120,9 \pm 32,86$ \\
\hline $\begin{array}{l}\text { Тривалість сухостійного періоду, } \\
\text { днів }\end{array}$ & $59,9 \pm 1,48$ & $46,8 \pm 8,96$ & $52,0 \pm 2,15^{*}$ & $56,9 \pm 2,32$ & $59,2 \pm 2,56$ \\
\hline $\begin{array}{l}\text { Тривалість міжотельного періоду, } \\
\text { днів (МОП) }\end{array}$ & $374,4 \pm 9,11$ & $345,6 \pm 19,12$ & $375,4 \pm 11,63$ & $403,1 \pm 35,65$ & $399,7 \pm 33,30$ \\
\hline $\begin{array}{l}\text { Коефіцієнт відтворювальної здатнос- } \\
\text { ті }\end{array}$ & $0,98 \pm 0,024$ & $1,06 \pm 0,052$ & $0,98 \pm 0,029$ & $0,94 \pm 0,064$ & $0,94 \pm 0,064$ \\
\hline Індекс адаптації (IA) & $-0,77 \pm 0,809$ & $1,64 \pm 1,273$ & $-0,57 \pm 0,744$ & $-1,58 \pm 1,770$ & $-1,88 \pm 2,306$ \\
\hline
\end{tabular}

Примітки: * $\mathrm{P}>0,95 ;$ ** $\mathrm{P}>0,99$; у порівнянні з бугаєм-плідником Судан 343015244.

Джерело: авторські дослідження.

Для селекції молочної худоби бажаними є плідники, потомство яких відрізняється високим проявом не лише молочності, а й жирномолочності та білковомолочності. До таких плідників відносяться бугаї Дензель 101431985 і Тандем 9434213. Їх дочки за вмістом жиру і білка в молоці переважають ровесниць, що походять від плідника Лаудана 578448776 , відповідно, на $0,10 \%$ і $0,04 \%$ та $0,12 \%(\mathrm{P}>0,95)$ і $0,03 \%$. Ця перевага спостерігається й за кількістю молочного жиру та білка. Різниця становила 20,8 кг і

Поряд із продуктивністю важливим елементом у селекційній роботі з молочною худобою $€$ відтворення тварин. Систематичне одержання приплоду забезпечує розмноження і використання цінних генотипів. Крім того, добра плодючість створює передумови для лактаційної функції корови, тим самим збільшуючи тривалість племінного використання тварин, а також $€$ параметром, який характеризує їхню адаптивну здатність [9]. 
2. Характеристика за господарсько корисними ознаками корів голштинськой породи німецької селекції, що походять від різних плідників (ІІ ГЕП, дочки), $\bar{X} \pm S x$

\begin{tabular}{|c|c|c|c|c|c|}
\hline \multirow[b]{2}{*}{ Ознака } & \multicolumn{5}{|c|}{ Кличка бугая, інв. №, лінія } \\
\hline & 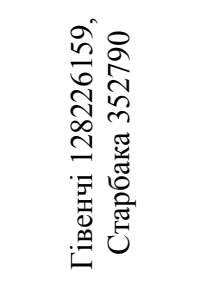 & 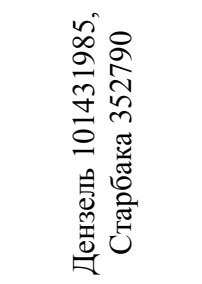 & 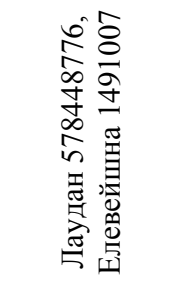 & 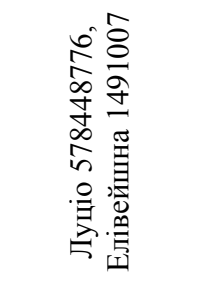 & 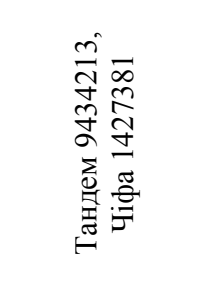 \\
\hline Враховано тварин, голів & 18 & 23 & 15 & 33 & 23 \\
\hline Тривалість лактації, днів & $347,5 \pm 33,26$ & $365,6 \pm 21,72^{*}$ & $309,3 \pm 7,18$ & $353,0 \pm 19,76^{*}$ & $329,6 \pm 12,20$ \\
\hline Надій за лактацію, кг & $10916 \pm 1140,3$ & $11611 \pm 688,3^{*}$ & $9640 \pm 350,0$ & $10204 \pm 625,4$ & $10162 \pm 380,3$ \\
\hline Надій за 305 днів лактації, кг & $9092 \pm 613,3$ & $9618 \pm 274,4$ & $9292 \pm 287,3$ & $8761 \pm 262,9$ & $9447 \pm 219,9$ \\
\hline Вміст жиру в молоці, \% & $3,99 \pm 0,047$ & $3,98 \pm 0,051$ & $3,88 \pm 0,041$ & $3,87 \pm 0,018$ & $4,00 \pm 0,037^{*}$ \\
\hline Кількість молочного жиру, кг & $360,7 \pm 23,69$ & $381,6 \pm 10,06$ & $360,8 \pm 11,97$ & $338,6 \pm 10,08$ & $377,7 \pm 12,26$ \\
\hline Вміст білка в молоці, \% & $3,22 \pm 0,020$ & $3,26 \pm 0,024$ & $3,22 \pm 0,005$ & $3,21 \pm 0,004$ & $3,25 \pm 0,022$ \\
\hline Кількість молочного білка, кг & $291,4 \pm 19,10$ & $313,7 \pm 8,18$ & $299,4 \pm 9,02$ & $280,8 \pm 8,38$ & $306,9 \pm 9,63$ \\
\hline $\begin{array}{l}\text { Кількість молочного жиру за } \\
\text { добу, кг }\end{array}$ & $1,25 \pm 0,055$ & $1,26 \pm 0,025$ & $1,21 \pm 0,041$ & $1,12 \pm 0,031$ & $1,24 \pm 0,045$ \\
\hline $\begin{array}{l}\text { Тривалість } \\
\text { сервіс-періоду, днів }\end{array}$ & $135,4 \pm 30,59$ & $136,5 \pm 20,57^{*}$ & $86,9 \pm 7,03$ & $133,0 \pm 21,12^{*}$ & $136,5 \pm 14,58 * *$ \\
\hline $\begin{array}{l}\text { Тривалість сухостійного пе- } \\
\text { ріоду, днів }\end{array}$ & $65,5 \pm 5,25$ & $66,1 \pm 10,49$ & $58,4 \pm 1,99$ & $59,9 \pm 3,10$ & $61,5 \pm 4,45$ \\
\hline $\begin{array}{l}\text { Тривалість міжотельного } \\
\text { періоду, днів }\end{array}$ & $415,1 \pm 30,76$ & $422,9 \pm 21,84 *$ & $348,6 \pm 18,47$ & $412,1 \pm 21,53^{*}$ & $391,6 \pm 14,62$ \\
\hline $\begin{array}{l}\text { Коефіцієнт відтворювальної } \\
\text { здатності }\end{array}$ & $0,94 \pm 0,054$ & $0,91 \pm 0,041$ & $1,14 \pm 0,147$ & $0,94 \pm 0,035$ & $0,95 \pm 0,027$ \\
\hline Індекс адаптації & $-0,77 \pm 1,632$ & $-2,38 \pm 1,072$ & $0,99 \pm 1,085$ & $-1,82 \pm 0,997$ & $-1,47 \pm 0,844$ \\
\hline
\end{tabular}

Примітки: * $\mathrm{P}>0,95$; ** $\mathrm{P}>0,99$; у порівнянні з бугаєм-плідником Лаудан 578448776.

Джерело: авторські дослідження.

Особливо це набуває значення при створенні високопродуктивного стада шляхом завезення маточного поголів'я спеціалізованої молочної породи, зокрема голштинської. Для імпортованої худоби допускається підвищена дія факторів зовнішнього середовища, що проявляється у зміні прояву відтворювальної здатності та індексу адаптації.

Порівняльним аналізом величин індексів адаптації у корів I і ІІ ГЕП не встановлено істотної різниці між дочками досліджуваних бугаївплідників, оскільки їх коливання знаходиться в межах від 1,64 до -1,88 і від 0,99 до -2,38 відповідно. Невисокі від'ємні індекси адаптації у потомства більшості бугаїв-батьків голштинської

породи свідчать про мінімізацію впливу факторів середовища. Зважаючи, що рівень індексу адаптації у корів-первісток залежить від тривалості міжотельного періоду (МОП), відмічаємо його подовження як в імпортованих тварин, так i власної репродукції. Винятком були дочки бугая Альвеса 255206543, у яких тривалість МОП становила 345,6 днів й індекс адаптації був 1,64. Позитивне значення індексу характеризує сприятливі технологічні умови, які забезпечують реалізацію спадкових задатків тварин голштинської породи. Їх середній надій за першу лактацію становив 9730 кг молока 3 вмістом жиру 3,94 \% i білка 3,19\%. Порівняно з коровами-первістками інших бугаїв I ГЕП від них отримано найбільшу 


\section{СІЛЬСЬКЕ ГОСПОДАРСТВО. ТВАРИННИЦТВО}

кількість молочного жиру за добу (1,28 кг). Серед корів-первісток голштинської породи II ГЕП оптимальною тривалістю міжотельного періоду характеризувалися дочки плідника Лаудана 578448776. У них МОП становив 348,6 днів та індекс адаптації - 0,99. Водночас встановлено деяке збільшення від'ємного індексу адаптації у корів, що народилися і були вирощені в умовах господарства. Це дочки бугая Дензеля 101431985, у яких індекс адаптації становив 2,38. Оскільки цей показник залежить від тривалості міжотельного періоду, який у високопродуктивних корів майже завжди подовжений, то це й пояснює значення індексу адаптації. Середній надій за першу лактацію становив 11611 кг молока з вмістом жиру 3,98 \% і білка 3,26 \%. Від них отримано найбільшу кількість молочного жиру за добу (1,26 кг) порівняно з ровесницями, що є дочками інших бугаїв-батьків.

Отже, серед оцінених імпортованих корівпервісток голштинської породи німецької селекції кращими за проявом господарсько корисних ознак були дочки бугаїв Джеферсона 347023457 , Лаудана 578448776 і Альвеса 255206543. У другому генетико-екологічному поколінні кращими за селекційними ознаками були дочки плідників Дензеля 101431985, Гівенчі 128226159 і Тандема 9434213.

Поряд з імпортованими голштинами та власної репродукції досліджено реалізацію спадковості голштинської породи української селекції за даними двох поколінь корів, що є дочками різних бугаїв-батьків. Встановлено різний рівень їх молочної продуктивності. Серед досліджуваного поголів'я материнського покоління вищою молочною продуктивністю характеризувалися дочки бугаїв Бюіка 10789585, Маркоса 131801949 і Реджімена 128891296. Їх надій за першу лактацію був вищим, відповідно, на 2649 кг (P>0,999), 1439 кг (P>0,95) і 1398 кг $(\mathrm{P}>0,99)$, ніж у ровесниць, батьком яких був плідник Делко 5296742.

Аналогічно зберігається вірогідна перевага й за іншими показниками продуктивності. Від них отримали більшу кількість молочного жиру і білка, відповідно, на 61,3 кг (P>0,999) i 48,4 кг $(\mathrm{P}>0,999)$; 34,6 кг $(\mathrm{P}>0,99)$ i 30,3 кг $(\mathrm{P}>0,99)$; 40,4 кг $(\mathrm{P}>0,99)$ і 35,5 кг $(\mathrm{P}>0,99)$ порівняно 3 дочками бугая Делко 5296742 (табл. 3).

Серед досліджуваних первісток дочірнього покоління кращим було потомство бугаїв Тандема 9434213, Дензеля 101431985 і Аладіна 7317441. Різниця за величиною надою за лактацію, порівняно з ровесницями, батьком яких був плідник Еуро 120030057965, відповідно, становила 2892 кг (Р>0,95), 2532 кг (P>0,99) і 1956 кг $(\mathrm{P}>0,95)$ молока. За іншими ознаками продуктивності також встановлено їх перевагу, що вказує на проведення поліпшуючої селекції при формуванні високопродуктивного стада (табл. 4).

Аналізуючи показники відтворювальної здатності корів голштинської породи української селекції, встановили, що потомство більшості плідників характеризувалося подовженою тривалістю сервіс- та міжотельного періодів. Проте в материнському поколінні найдовшою тривалістю цих періодів відрізнялися дочки бугая Коеніга 577023256. Різниця порівняно з ровесницями, батьком яких є плідник Делко 5296742, відповідно, становила 78,6 днів (P>0,99) і 86,1 дня $(\mathrm{P}>0,99)$.

У дочірньому поколінні найбільшою тривалістю сервіс- та міжотельного періодів характеризувалося потомство двох бугаїв. Це дочки плідників Дензеля 101431985 і Тандема 9434213, у яких значення сервіс періоду та МОП більші, відповідно, на 77,4 дня (P>0,999) та 76,6 дня $(\mathrm{P}>0,999)$ і 72,5 дня $(\mathrm{P}>0,95)$ та 73,6 дня $(\mathrm{P}>0,95)$ порівняно 3 ровесницями, що походять від бугая Еуро 120030057965.

Для потомства бугаїв голштинської породи, що утворюють популяцію голштинів української селекції характерні від'ємні індекси адаптації, рівень яких коливався від -0,21 до -6,13 у материнському поколінні.

Зі зміною покоління спостерігається деяке підвищення значень індексу адаптації (-0,13 -4,22). Рівень від'ємних індексів -4,22 і -3,86 у дочок бугаїв Дензеля 101431985 і Тандема 9434213 свідчить не про невідповідність умов середовища, а є підтвердженням існування природного антагонізму високої продуктивності корів-первісток 3 їх відтворювальною здатністю. Тому при одночасній селекції молочної худоби варто звертати увагу на поліпшуючий вплив бугаїв-плідників, не лише на їхні продуктивні ознаки, а й на відтворювальні якості.

Нами встановлено взаємозв'язок між ознаками молочної продуктивності корів-первісток голштинської породи німецької та української селекції, які походять від різних бугаїв. Зважаючи на те, що імпортовані тварини продукують у нових технологічних умовах, і це викликає певну зміну кореляційних зв'язків між селекційними ознаками. У результаті порівняльного аналізу встановлено від'ємну кореляцію низького та середнього ступенів між надоєм і вмістом жиру в молоці у дочок бугаїв Судана 343015244, Джу- 


\section{СІЛЬСЬКЕ ГОСПОДАРСТВО. ТВАРИННИЦТВО}

руса 768076721, Лаудана 578448776 (I ГЕП) i Луціо 578448776, Гівенчі 128226159, Дензеля 101431985 (II ГЕП). Проте виявлено і позитивну залежність між молочністю і жирномолочністю у потомства плідників Альвеса 255206543, Джеферсона 347023457 (І ГЕП) і Лаудана 578448776 (II ГЕП).

Аналогічна тенденція взаємозв'язку спостерігається між ознаками надій і вміст білка в молоці. У більшості досліджуваного потомства бугаїв голштинської породи виявлено від'ємну кореляцію між молочністю та білковомолочністю, за винятком дочок бугая Альвеса 255206543, коефіцієнт кореляції у яких становив 0,44 . Встановлено позитивний зв'язок середнього і високого ступенів між вмістом жиру та білка в молоці, за винятком дочок бугая Тандема 9434213. Для потомства плідників Судана 343015244 (I ГЕП) i Лаудана 578448776 (II ГЕП) характерна позитивна високого ступеня кореляція $(\mathrm{r}=0,78 \mathrm{P}>0,99 \mathrm{i}$ $\mathrm{r}=0,74 \mathrm{P}>0,999$ відповідно).

Щодо зв'язку між надоєм і кількістю молочного жиру та білка, то виявлено позитивну залежність високого ступеня ( $\mathrm{r}=0,91-0,99$ i $\mathrm{r}=0,96-$ 0,99 Р>0,999 відповідно). Така кореляція спостерігається у дочок всіх бугаїв-плідників, що є батьками імпортованих тварин та власної репродукції.

\section{3. Характеристика за господарсько корисними ознаками корів голитинської породи}

украӥнської селекції, щңо походять від різних плідників (матері), $\bar{X} \pm S x$

\begin{tabular}{|c|c|c|c|c|c|c|c|}
\hline \multirow[b]{2}{*}{ Ознака } & \multicolumn{7}{|c|}{ Кличка бугая, інв. №, лінія } \\
\hline & 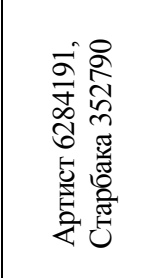 & 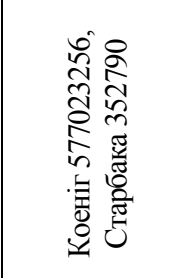 & 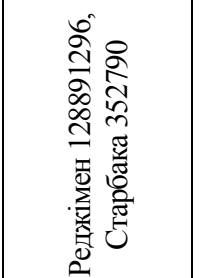 & 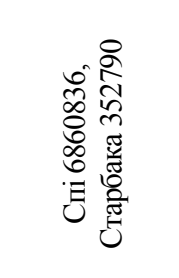 & 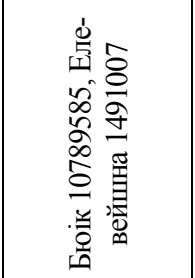 & 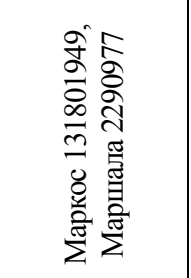 & 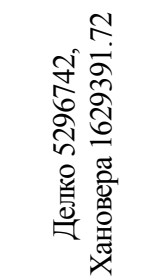 \\
\hline $\mathrm{n}$ & 10 & 16 & 12 & 27 & 28 & 23 & 29 \\
\hline Тривалість лактації, днів & $351,1 \pm 28,22$ & $399,6 \pm 24,54 * *$ & $330,9 \pm 16,99$ & $334,2 \pm 10,86$ & $354,3 \pm 19,56$ & $334,2 \pm 17,04$ & $323,3 \pm 11,37$ \\
\hline Надій за лактацію, кг & $9180 \pm 879,1$ & $9449 \pm 485,2 * *$ & $9217 \pm 448,4^{* *}$ & $8687 \pm 362,3^{*}$ & \begin{tabular}{|c|}
$10288 \pm 585,5^{* *}$ \\
$*$
\end{tabular} & $9258 \pm 513,4^{*}$ & $7819 \pm 235,0$ \\
\hline Надій за 305 днів, кг & $7871 \pm 444,2$ & $7811 \pm 290,9$ & $8479 \pm 235,3^{* * *}$ & $7995 \pm 266,0^{*}$ & $8904 \pm 287,6 * * *$ & $8271 \pm 247,5^{* *}$ & $7320 \pm 201,7$ \\
\hline Вміст жиру в молоці, \% & $3,91 \pm 0,061$ & $3,90 \pm 0,070$ & $3,90 \pm 0,027$ & $4,00 \pm 0,026$ & $3,95 \pm 0,030$ & $3,93 \pm 0,025$ & $3,98 \pm 0,029$ \\
\hline $\begin{array}{l}\text { Кількість молочного жиру, } \\
\text { Кг }\end{array}$ & $309,4 \pm 21,32$ & $304,5 \pm 11,95$ & $330,9 \pm 9,20 * * *$ & $319,8 \pm 10,47^{*}$ & $\begin{array}{c}351,8 \pm 12,16 * * \\
*\end{array}$ & $325,1 \pm 9,67 * *$ & $290,5 \pm 6,96$ \\
\hline Вміст білка в молоці, \% & $3,19 \pm 0,018$ & $3,16 \pm 0,020$ & $3,16 \pm 0,024$ & $3,16 \pm 0,016$ & $3,16 \pm 0,013$ & $3,18 \pm 0,010$ & $3,18 \pm 0,009$ \\
\hline $\begin{array}{l}\text { Кількість молочного білка, } \\
\text { кг }\end{array}$ & $251,4 \pm 14,43$ & $247,2 \pm 9,85$ & $268,4 \pm 8,55^{* *}$ & $253,0 \pm 8,37$ & $281,3 \pm 9,33 * * *$ & $263,2 \pm 7,86^{* *}$ & $232,9 \pm 6,46$ \\
\hline $\begin{array}{l}\text { Кількість молочного жиру } \\
\text { за добу, кг }\end{array}$ & $1,02 \pm 0,067$ & $0,94 \pm 0,040$ & $0,96 \pm 0,029$ & $1,04 \pm 0,032$ & $1,15 \pm 0,033$ & $1,09 \pm 0,033^{* *}$ & $0,97 \pm 0,024$ \\
\hline $\begin{array}{l}\text { Тривалість } \\
\text { сервіс-періоду, днів }\end{array}$ & $127,6 \pm 28,74$ & $176,1 \pm 23,68 * *$ & $106,5 \pm 17,21$ & $111,8 \pm 11,07$ & $131,8 \pm 19,76$ & $110,9 \pm 16,92$ & $97,5 \pm 9,56$ \\
\hline $\begin{array}{l}\text { Тривалість сухостійного } \\
\text { періоду, днів }\end{array}$ & $55,4 \pm 2,24$ & $60,0 \pm 3,21$ & $55,6 \pm 2,32$ & $57,2 \pm 2,38$ & $57,7 \pm 1,09$ & $53,5 \pm 1,48^{* *}$ & $61,8 \pm 2,62$ \\
\hline $\begin{array}{l}\text { Тривалість міжотельного } \\
\text { періоду, днів }\end{array}$ & $406,5 \pm 29,01$ & $458,1 \pm 23,79 * *$ & $386,5 \pm 16,99$ & $385,7 \pm 12,76$ & $408,7 \pm 20,15$ & $387,5 \pm 17,07$ & $372,0 \pm 11,04$ \\
\hline $\begin{array}{l}\text { Коефіцієнт відтворювальної } \\
\text { здатності }\end{array}$ & $0,93 \pm 0,058$ & $0,83 \pm 0,042 * *$ & $0,96 \pm 0,038$ & $0,97 \pm 0,031$ & $0,94 \pm 0,036$ & $0,97 \pm 0,033$ & $1,00 \pm 0,028$ \\
\hline Індекс адаптації & $-1,91 \pm 1,861$ & $-6,13 \pm 1,536^{* *}$ & $-1,17 \pm 1,124$ & $-1,22 \pm 0,896$ & $-1,72 \pm 1,115$ & $-0,77 \pm 0,948$ & $-0,21 \pm 0,885$ \\
\hline
\end{tabular}

Примітки: * $\mathrm{P}>0,95 ;$ ** $\mathrm{P}>0,99 ;$ *** $\mathrm{P}>0,999$ у порівнянні з бугаєм-плідником Делко 5296742.

Джерело: авторські дослідження. 
СІЛЬСЬКЕ ГОСПОДАРСТВО. ТВАРИННИЦТВО

\section{4. Характеристика за господарсько корисними ознаками корів голштинськой породи украӥнської селекції, що походять від різних плідників (дочки), $\bar{X} \pm S x$}

\begin{tabular}{|c|c|c|c|c|c|c|c|c|}
\hline \multirow[b]{2}{*}{ Ознака } & \multicolumn{8}{|c|}{ Кличка бугая, інв. №, лінія } \\
\hline & $\begin{array}{c}\text { Дензель } \\
\text { 101431985, } \\
\text { Старбака } \\
352790\end{array}$ & $\begin{array}{c}\text { Букмен } \\
7355185, \\
\text { Старбака } \\
352790\end{array}$ & $\begin{array}{c}\text { Манікс } \\
\text { 128891296, } \\
\text { Старбака } \\
352790\end{array}$ & $\begin{array}{c}\text { Долман } \\
60540099, \\
\text { Маршала } \\
2290977\end{array}$ & $\begin{array}{c}\text { Тандем } \\
9434213, \\
\text { Чіфа } 1427381\end{array}$ & $\begin{array}{c}\text { Eypo } \\
1200300579 \\
65 \\
\text { Чiфa } \\
1427381 \\
\end{array}$ & $\begin{array}{c}\text { Брадок } \\
7355181, \\
\text { Чіфа } \\
1427381\end{array}$ & $\begin{array}{c}\text { Аладін } \\
7317441, \\
\text { Чіфа } \\
1427381\end{array}$ \\
\hline $\mathrm{n}$ & 32 & 17 & 13 & 10 & 10 & 25 & 13 & 20 \\
\hline $\begin{array}{l}\text { Тривалість } \\
\text { лактації, днів }\end{array}$ & $\begin{array}{c}392,5 \pm 18,18 \\
* *\end{array}$ & $351,4 \pm 16,35$ & $356,8 \pm 26,39$ & $340,7 \pm 46,68$ & $390,5 \pm 36,37$ & $316,0 \pm 14,34$ & $328,8 \pm 16,03$ & $351,8 \pm 19,39$ \\
\hline $\begin{array}{l}\text { Надій за лак- } \\
\text { тацію, кг }\end{array}$ & $\begin{array}{c}12020 \pm 754 \\
6^{* *}\end{array}$ & $\begin{array}{c}10792 \pm 599 \\
4 \\
\end{array}$ & $\begin{array}{c}\text { 10722 } \pm 724 \\
2\end{array}$ & $\begin{array}{c}11010 \pm 1921 \\
, 6 \\
\end{array}$ & $\begin{array}{c}12380 \pm 1106,9 \\
*\end{array}$ & $9488 \pm 392,4$ & $\begin{array}{c}10164 \pm 540 \\
1\end{array}$ & $\begin{array}{c}11444 \pm 705 \\
4 *\end{array}$ \\
\hline $\begin{array}{l}\text { Надій за } 305 \\
\text { днів, кг }\end{array}$ & $9556 \pm 319,2$ & $9484 \pm 360,3$ & $9399 \pm 473,0$ & $9455 \pm 695,7$ & $10121 \pm 512,8^{*}$ & $8874 \pm 223,8$ & $9317 \pm 365,1$ & $\begin{array}{c}9877 \pm 346,8 \\
* \\
\end{array}$ \\
\hline $\begin{array}{l}\text { Вміст жиру в } \\
\text { молоці, \% }\end{array}$ & $3,94 \pm 0,049 *$ & $\begin{array}{c}3,94 \pm 0,035^{*} \\
*\end{array}$ & $3,94 \pm 0,061$ & $4,14 \pm 0,191$ & $4,01 \pm 0,077^{*}$ & $3,82 \pm 0,011$ & $3,88 \pm 0,034$ & $3,86 \pm 0,033$ \\
\hline $\begin{array}{l}\text { Кількість } \\
\text { молочного } \\
\text { жиру, кг } \\
\end{array}$ & $\begin{array}{c}377,8 \pm 14,11 \\
*\end{array}$ & $\begin{array}{c}373,5 \pm 13,59 \\
*\end{array}$ & $368,5 \pm 16,80$ & $392,8 \pm 36,39$ & $410,0 \pm 20,15^{* *}$ & $338,8 \pm 8,53$ & $361,0 \pm 13,80$ & $\begin{array}{c}380,6 \pm 12,16 \\
* *\end{array}$ \\
\hline $\begin{array}{l}\text { Вміст білка в } \\
\text { молоці, \% }\end{array}$ & $3,23 \pm 0,026$ & $\begin{array}{c}3,28 \pm 0,012 * \\
* *\end{array}$ & $3,22 \pm 0,014$ & $3,34 \pm 0,079$ & $3,30 \pm 0,033$ & $3,21 \pm 0,009$ & $3,24 \pm 0,012$ & $3,22 \pm 0,015$ \\
\hline $\begin{array}{l}\text { Кількість } \\
\text { молочного } \\
\text { білка, кг } \\
\end{array}$ & $308,9 \pm 11,01$ & $310,5 \pm 11,30$ & $302,8 \pm 15,00$ & $316,6 \pm 26,09$ & $333,3 \pm 15,10^{* *}$ & $285,0 \pm 7,20$ & $301,7 \pm 8,59$ & $\begin{array}{c}318,0 \pm 10,60 \\
* *\end{array}$ \\
\hline $\begin{array}{l}\text { Кількість } \\
\text { молочного } \\
\text { жиру за добу, } \\
\text { кг }\end{array}$ & $1,20 \pm 0,045$ & $1,21 \pm 0,043$ & $1,20 \pm 0,055$ & $1,32 \pm 0,112$ & $1,29 \pm 0,062 *$ & $1,15 \pm 0,028$ & $1,20 \pm 0,049$ & $1,26 \pm 0,041^{*}$ \\
\hline $\begin{array}{l}\text { Тривалість } \\
\text { сервіс- } \\
\text { періоду, днів }\end{array}$ & $\begin{array}{c}172,0 \pm 18,29 \\
* * *\end{array}$ & $137,1 \pm 20,47$ & $135,4 \pm 26,41$ & $118,5 \pm 46,93$ & $167,1 \pm 32,82 *$ & $94,6 \pm 13,40$ & $107,5 \pm 16,07$ & $126,6 \pm 18,52$ \\
\hline $\begin{array}{l}\text { Тривалість } \\
\text { сухостійн } \\
\text { періоду, днів }\end{array}$ & $59,0 \pm 1,57$ & $65,8 \pm 6,32$ & $59,3 \pm 2,28$ & $56,8 \pm 2,55$ & $58,1 \pm 4,20$ & $59,5 \pm 1,20$ & $58,7 \pm 1,94$ & $53,2 \pm 2,99$ \\
\hline МОП, днів & $\begin{array}{c}451,6 \pm 18,28 \\
* * *\end{array}$ & $417,2 \pm 20,64$ & $416,2 \pm 25,87$ & $397,5 \pm 47,54$ & $448,6 \pm 33,81^{*}$ & $375,0 \pm 13,75$ & $387,5 \pm 15,55$ & $405,0 \pm 18,71$ \\
\hline КВ3 & $\begin{array}{c}0,84 \pm 0,030^{*} \\
* *\end{array}$ & $0,90 \pm 0,037^{*}$ & $0,91 \pm 0,049$ & $0,98 \pm 0,065$ & $0,85 \pm 0,055^{*}$ & $1,00 \pm 0,026$ & $0,96 \pm 0,035$ & $0,93 \pm 0,035$ \\
\hline IA & $\begin{array}{c}-4,22 \pm 0,844 \\
* * *\end{array}$ & $-2,81 \pm 1,170$ & $-2,49 \pm 1,473$ & $-0,24 \pm 1,437$ & $-3,86 \pm 1,427^{*}$ & $-0,13 \pm 0,768$ & $-1,21 \pm 0,991$ & $-1,70 \pm 0,868$ \\
\hline
\end{tabular}

Примітки: * $\mathrm{P}>0,95 ;$ ** $\mathrm{P}>0,99 ;$ *** $\mathrm{P}>0,999$ у порівнянні з бугаєм-плідником Еуро 120030057965.

Джерело: авторські дослідження.

Щодо зв'язку між надоєм і кількістю молочного жиру та білка, то виявлено позитивну залежність високого ступеня $(\mathrm{r}=0,91-0,99 \mathrm{i} \mathrm{r}=0,96-$ $0,99 \mathrm{P}>0,999$ відповідно). Така кореляція спостерігається у дочок всіх бугаїв-плідників, що є батьками імпортованих тварин та власної репродукції.

Для корів-первісток голштинської породи української селекції характерним $\epsilon$ наявність позитивної кореляції середнього ступеня між надоєм і вмістом жиру в молоці. Це дочки бугая Артиста 6284191, у яких $\mathrm{r}=0,62$ (P>0,95). Аналогічної величини, але від'ємний коефіцієнт кореляції визначено для потомства бугая
Делко 5296742 ( $\mathrm{r}=-0,62 \mathrm{P}>0,999)$.

Серед потомства досліджуваних плідників у дочірньому поколінні позитивний зв'язок між надоєм і вмістом жиру в молоці встановлено для корів-первісток, батьком яких був бугай Дензель $101431985(\mathrm{r}=0,21)$. Водночас у дочок більшості плідників відмічаємо від'ємну кореляцію молочності та жирномолочності $(\mathrm{r}=-0,09--0,57)$. Між надоєм і вмістом білка в молоці також встановлено від'ємну кореляцію. Підтвердженням цього $\epsilon$ значення коефіцієнтів кореляції у дочок плідників Букмена $7355185(\mathrm{r}=-0,52 \mathrm{P}>0,99)$ і Тандема $9434213(\mathrm{r}=-0,67 \mathrm{P}>0,99)$.

Нашими дослідженнями підтверджено наяв- 


\section{СІЛЬСЬКЕ ГОСПОДАРСТВО. ТВАРИННИЦТВО}

ність позитивної кореляції середнього та високого ступеня між вмістом жиру і білка в молоці у дочок різних бугаїв. Потомство плідників Еуро 120030057965, Тандема 9434213, Аладіна 7317441, Дензеля 101431985 і Долмана 60540099 характеризується такими значеннями: $\mathrm{r}=0,56$ $\mathrm{P}>0,999 ; \quad r=0,58 \quad \mathrm{P}>0,95 ; \quad r=0,63 \quad \mathrm{P}>0,999$; $\mathrm{r}=0,78 \mathrm{P}>0,999 ; \mathrm{r}=0,93 \mathrm{P}>0,999$. Незалежно від походження піддослідних тварин зберігається позитивна високого ступеня кореляція між надо$\epsilon м$ і кількістю молочного жиру та білка. Можна вважати це закономірним явищем, оскільки кореляційна залежність є високо вірогідною (r = 0,86-0,99 $\mathrm{P}>0,999)$. Такий рівень і напрям співвідносної мінливості вказує на високу результативність одночасної селекції за цими ознаками.

Про існування природного антагонізму між продуктивними і відтворювальними ознаками у молочної худоби свідчать результати аналізу зв'язків між молочністю і показниками відтворювальної здатності дочок різних бугаїв-батьків. Загальною закономірністю для потомства бугаїв голштинської породи є наявність позитивної кореляції низького, середнього і високого ступенів між надоєм і тривалістю сервіс-періоду. Серед імпортованого поголів'я (I ГЕП) лише дочки плідників Судана 343015244 i Джуруса 768076721 характеризувалися низьким і середнім ступенем коефіцієнтів кореляції ( $\mathrm{r}=0,16 \mathrm{i}$ $\mathrm{r}=0,55)$.

Серед тварин власної репродукції потомство двох бугаїв мало середній ступінь кореляції. Це дочки плідників Лаудана 578448776 і Тандема 9434213 ( $\mathrm{r}=0,45 \mathrm{P}>0,95$ і $\mathrm{r}=0,60 \mathrm{P}>0,999)$. Аналогічну закономірність кореляційної залежності у потомства досліджуваних бугаїв встановлено між надоєм і тривалістю міжотельного періоду ( $\mathrm{r}=0,24-0,96$ i r =0,50-0,95). Про явний антагонізм ознак продуктивності та відтворювальної здатності свідчить зв'язок між надоєм і коефіцієнтом відтворювальної здатності у потомства досліджуваних бугаїв. Дочки майже всіх плідників характеризувалися від'ємною кореляцією, яка коливалася в межах від -0,26 до -0,98. Винятком було потомство бугая Лаудана 578448776 , у якого встановлено позитивну кореляцію середнього ступеня $(\mathrm{r}=0,62 \mathrm{P}>0,999)$. I не лише між надоєм і КВ3, а й між надоєм та індексом адаптації, що зі свого боку свідчить про високі адаптаційні якості дочок цього плідника. Дочки інших бугаїв характеризувалися від'ємною кореляцією між молочністю та індексом адаптації (r $=-0,16--0,98$ при $\mathrm{P}>0,999)$.
Отже, встановлені відмінності за напрямом i ступенем кореляційної залежності між продуктивними і відтворювальними ознаками характеризують різноманітність впливу бугаїв на їхніх дочок, що потрібно враховувати у процесі поліпшуючої селекції під час формування високопродуктивного стада молочної худоби голштинської породи.

\section{Висновки та перспективи досліджень:}

1. На рівень продуктивності корів впливає їх походження за батьком. Серед оцінених імпортованих корів-первісток голштинської породи німецької селекції кращими були дочки бугаїв Джеферсона 347023457, Лаудана 578448776. Piвень надою дочок плідника Альвеса 255206543 на 1390 кг (Р>0,95) більший, ніж у ровесниць від бугая Судана 343015244. У другому генетикоекологічному поколінні - потомство плідників Дензеля 101431985, Гівенчі 128226159 і Тандема 9434213. Різниця за величиною надою за лактацію порівняно з ровесницями, батьком яких був плідник Лаудан 578448776, відповідно, становила 1971 кг $(\mathrm{P}>0,95), 1276$ кг, 564 кг і 522 кг молока.

2. Серед досліджуваних тварин голштинської породи української селекції материнського і дочірнього поколінь вища молочна продуктивність наявна у дочок бугаїв Бюіка 10789585, Маркоса 131801949, Реджімена 128891296 і Тандема 9434213, Дензеля 101431985 і Аладіна 7317441. Їх надій за першу лактацію був більшим, відповідно, на 2649 кг (Р>0,999), 1439 кг $(\mathrm{P}>0,95)$, 1398 кг (Р>0,99), ніж у ровесниць, батьком яких був плідник Делко 5296742 і 2892 кг (P>0,95), 2532 кг (P>0,99) і 1956 кг (Р>0,95) молока порівняно 3 ровесницями, батьком яких був плідник Еуро 120030057965, відповідно.

3. Встановлено відмінності за напрямом i ступенем кореляційної залежності між продуктивними і відтворювальними ознаками у корівпервісток, що характеризують різноманітність впливу бугаїв на їхніх дочок. У дочок усіх бугаїв-плідників, що $є$ батьками імпортованих тварин та власної репродукції виявлено між надоєм і кількістю молочного жиру та білка позитивну залежність високого ступеня $(\mathrm{r}=0,91-0,99$ i $\mathrm{r}=$ 0,96-0,99 $\mathrm{P}>0$,999).

На перспективу пропонуємо дослідити вплив бугаїв-плідників голштинської породи на тривалість господарського використання та пожиттєву продуктивність тварин. 


\section{БІБЛІОГРАФІЯ}

1. Бірюкова О. Д. Про роль генотипу плідника у селекційному процесі. Розведення $i$ генетика тварин. 2010. Вип. 44. С. 17-20.

2. Клопенко Н. І., Рудик I. А. Використання селекційно-генетичних параметрів у селекції стада молочної худоби. Технологія виробництва i переробки продукиії тваринництва : зб. наук. праць. Біла Церква, 2010. Вип. 3 (72). C. $180-183$.

3. Козловська М. В. Генеалогічна структуризація голштинської популяції Придніпров'я. Розведення і генетика тварин. 2005. Вип. 38. C. $158-164$.

4. Литвиненко Т. В., Тимченко О. Г. Продуктивність корів голштинської породи різних ліній. Розведення і генетика тварин. 2005. Вип. 38. C. 164-166.

5. Мунтяну Г. Л. Совершенствование молочних стад путем использования быков голштинской породы. Розведення $i$ генетика тварин. 1999. Вип. 31-32. С. 164-165.

6. Пат. 15061 А Україна, МКВ А 01 К 67/00 Спосіб оцінки якості генотипу бугая / Полковникова О. П.; заявник і патентовласник Інститут тваринництва Української академії аграрних наук. № 9405074; заявл. 11.05.94 ; опубл. 30.06.97. Бюл. № 3.5 c.

7. Пелехатий М. С., Піддубна Л. М. Роль бугаїв-плідників у формуванні відкритої популяції чорно-рябої породи північно-подільського регіону. Технологія виробництва і переробки проду-

\section{REFERENSES}

1. Biryukova, O. D. (2010). Pro rolj ghenotypu plidnyka u selekcijnomu procesi [About the role of the genotype of the plidnik at the selective process]. Rozvedennja $i$ ghenetyka tvaryn : mizhvidom. tematych. nauk. zb., 44, pp. 17-20 [In Ukrainian].

2. Klopenko, N. I., Rudik, I. A. (2010). Vykorystannja selekcijno-ghenetychnykh parametriv u selekciji stada molochnoji khudoby [Vikoristannya selection of genetic parameters in the selection of the herds of milk and thinness]. Tekhnologhija vyrobnyctva $i$ pererobky produkciji tvarynnyctva : zb. nauk. pracj, 3 (72), pp. 180-183 [In Ukrainian].

3. Kozlovska, M. V. (2005). Ghenealoghichna strukturyzacija gholshtynsjkoji populjaciji Prydniprov'ja [Genealogical Structuring of the Holstein Population of Pridniprov'ya]. Rozvedennja $i$ ghenetyka tvaryn : mizhvidom. tematych. nauk. zb., 38, pp. 158-164 [In Ukrainian]. киії тваринництва. 2010. Вип. 3 (72). С. 88-92.

8. Пелехатий М. С., Піддубна Л. М. Племінний підбір у відкритій популяції молочної худоби. Технологія виробництва і переробки продукції тваринництва. 2012. Вип. 7 (90). С. 94-98.

9. Підпала T. В. Вплив бугаїв поліпшуючих порід на результативність селекції червоної степової худоби. Проблеми становлення галузі тваринництва в сучасних умовах : матеріали наук.практ. конф. Вінниця : ТД «Едельвейс і К», 2005. Вип. 22. Ч. 1. С. 129-133.

10. Підпала Т. В., Бондар С. О. Успадкування селекційних ознак потомством бугаїв-плідників голштинської породи. Розведення $і$ генетика тварин. 2017. Вип. 53. С. 173-179.

11. Плохинский Н. А. Руководство по биометрии для зоотехников. М. : Колос, 1969. 255 с.

12. Селекція молочної худоби і свиней : навч. посіб. [Т. В. Підпала та ін.] ; за ред. Т. В. Підпалої. Миколаїв : МНАУ, 2012. 297 с.

13. Сич М. П., Чирик I. І., Шиховиова С. К. Екстер'єр і продуктивні якості корів червоної степової породи та іiї помісей з червоно-рябою голштинською породою. Розведення та штучне осіменіння великої рогатої худоби. 1994. Вип. 26. C. 33-35.

14. Формування високопродуктивного стада молочної худоби / В. П. Даниленко, І. А. Рудик, В. П. Олешко, О. І. Бабенко. Технологія виробниичтва і переробки продукції тваринництва. 2010. Вип. 3 (72). С. 73-76.

4. Litvinenko, T. V., Timchenko, O. G. (2005). Produktyvnistj koriv gholshtynsjkoji porody riznykh linij [Productivity of cows of golshtinskoy of breed of different lines]. Rozvedennja i ghenetyka tvaryn : mizhvidom. tematych. nauk. zb., 38, pp. 164-166 [In Ukrainian].

5. Muntyanu, G. L. (1999). Sovershenstvovanye molochnykh stad putem yspoljzovanyja bыkov gholshtynskoj porod [Sovershenstvovanie sucklings herds of putem ispol'zovaniya bykov golshtinskoy porody]. Rozvedennja $i$ ghenetyka tvaryn : mizhvidom. tematych. nauk. zb., 31-32, pp. 164-165 [In Russian].

6. Polkovnikova, O. P. Pat. 15061 A Ukrajina, MKV A 01 K 67/00 Sposib ocinky jakosti ghenotypu bughaja zajavnyk $i$ patentovlasnyk Instytut tvarynnyctva Ukrajinsjkoji akademiji aghrarnykh nauk [Method of estimation of quality of genotype of bugaya declarant and patentovlasnik Institute of 


\section{СІЛЬСЬКЕ ГОСПОДАРСТВО. ТВАРИННИЦТВО}

stock-raising of the Ukrainian academy of agrarian sciences: pat. 15061 Ukraine]. 9405074; zajavl. 11.05.94 ; opubl. 30.06.97. Bjul. 3:5 [In Ukrainian].

7. Pelekhatyj, M. S. Piddubna, L. M. (2010). Rolj bughajiv-plidnykiv u formuvanni vidkrytoji populjaciji chorno-rjaboji porody pivnichnopodiljsjkogho reghionu [The role of bulls-breeders in the formation of an open population of black-andrudimentary breed in the North Podolsk region]. Tekhnologhija vyrobnyctva $i$ pererobky produkciji tvarynnyctva: zb. nauk. pracj, 3(72), pp. 88-92 [In Ukrainian].

8. Pelekhatyj, M. S., Piddubna, L. M. (2012). Pleminnyj pidbir u vidkrytij populjaciji molochnoji khudoby [Breeding selection in an open population of dairy cattle]. Tekhnologhija vyrobnyctva $i$ pererobky produkciji tvarynnyctva: zb. nauk. pracj, 7(90), pp. 94-98 [In Ukrainian].

9. Pidpala, T. V. (2005). Vplyv bughajiv polipshujuchykh porid na rezuljtatyvnistj selekciji chervonoji stepovoji khudoby [Influence of bulls of improving breeds on the efficiency of breeding of red steppe livestock]. Problemy stanovlennja ghaluzi tvarynnyctva $v$ suchasnykh umovakh : materialy naukovo-praktychnoji konferenciji. Vinnycja: TD «Edeljvejs i K», 22(1), pp. 129-133 [In Ukrainian].

10. Pidpala, T. V., Bondar, S. O. (2017). Uspadkuvannja selekcijnykh oznak potomstvom bughajiv-plidnykiv gholshtynsjkoji porody [Inheritance of breeding grounds by the offspring of bulls-breeders of the Holstein breed]. Rozvedennja $i$ ghenetyka tvaryn : mizhvidomch. temat. nauk. zb., 53, pp. 173-179 [In Ukrainian].

11. Plokhynskyi, N. A. (1969). Rukovodstvo po byometryy dlia zootekhnykov [Guide for biometrics for livestock breeders]. Moskva: Kolos [In Russian].

12. Pidpala, T. V., Vojnalovych, S. A., Nazarenko, V. G. and others (2012). Selekciya molochnoyi xudoby'i svy nej : navch. posib. [Selection of dairy cattle and pigs : teach. manual]. Mykolaiv: MNAU [In Ukrainian].

13. Sich, M. P. (1994). Ekster'jer i produktyvni jakosti koriv chervonoji stepovoji porody ta jiji pomisej $\mathrm{z}$ chervono-rjaboju gholshtynsjkoju porodoju [Exter'uer and the productive activities of the Chervonian steppe breed and the Holy Wings of the Holstein breed]. Rozvedennja ta shtuchne osimeninnja velykoji roghatoji khudoby : mizhvidom. tematych. nauk. zb., 26, pp. 33-35 [In Ukrainian].

14. Danylenko, V. P. (2010). Formuvannja vysokoproduktyvnogho stada molochnoji khudoby [Formation of a highly productive herd of dairy cattle]. Tekhnologhija vyrobnyctva $i$ pererobky produkciji tvarynnyctva: zb. nauk. pracj, 3 (72), pp. 73-76 [In Ukrainian].

\section{Подпалая Т. В., Зайцев Е. Н., Правда А. А. Результаты использования быков-производителей голштинской породы при создании высокопродуктивного стада}

Цель статьи - оценить проявление хозяйственно-полезных признаков у коров-дочерей разных быков-производителей голштинской породы.

Методика исследований. В процессе исследований использованы общепринятые зоотехнические методы (индивидуальный учёт молочной продуктивности, воспроизводительной способности), лабораторные (определение качественного состава молока), ретроспективный анализ (показатели за весь период использования животных), вариационно-статистический метод (определение параметров признаков).

Результаты исследования. В результате использования быков-производителей голштинской породы при создании высокопродуктивного стада молочного скота установлено, что на уровень развития продуктивных, воспроизводительных и адаптационных свойств коров-дочерей влияет происхождение по отиу. Установлена взаимосвязь между хозяйственно полезными признаками коровпервотёлок голштинской породы немецккой и украинской селекции, которые происходят от разных быков. Независимо от происхождения подопытных животных сохраняется положительная высокой степени корреляция между удоем и количеством молочного жира и белка. Общей закономерностью для потомства быков голштинской породы является положительная корреляция низкой, средней и высокой степени между удоем и продолжительностью сервис-периода. Определень отличия за направлением и степенью корреляционной зависимости между продуктивными и воспроизводительными признаками у коров-первотелок, которые и характеризуют разнообразие влияния быков на их дочерей.

Элементы научной новизны. Получили дальнейшее развитие теоретические и практические положения о повышении продуктивности животных и создании высокопродуктивных стад молочного 
скота с ипользованием генофонда голитинской породы.

Практическое значение. Полученные результаты следует учитывать в прочессе улучшающей селекиии во время формирования высокопродуктивного стада молочного скота голитинской nороды.

Ключевые слова: голитинская порода, поколение, молочная продуктивность, воспроизводительная способность, индекс адаптацуии, корреляциия.

Подпалая Татьяна Васильевна- доктор сельскохозяйственных наук, профессор, заведующая кафедрой технологии переработки, стандартизации и сертификации продукции животноводства, Николаевский национальный аграрный университет, ул. Г. Гонгадзе, 9, г. Николаев, 54020, Украина, e-mail: pidpala@mnau.edu.ua, ORCID ID: 0000-0002-4072-7576.

Зайцев Евгений Николаевич- соискатель высшего образования степени доктора философии кафедры технологии переработки, стандартизации и сертификации продукции животноводства, Николаевский национальный аграрный университет, ул. Г. Гонгадзе, 9, г. Николаев, 54020, Украина, e-mail: zaitsev_yevhen@ukr.net, ORCID ID: 0000-0002-4165-4196.

Правда Анастасия Александровна- магістр, кафедра технологии переработки, стандартизации и сертификации продукции животноводства, Николаевский национальный аграрный университет, ул. Г. Гонгадзе, 9, г. Николаев, 54020, Украина, e-mail: pravdanasta@gmail.com.

Pidpala T. V., Zaitsev Ye. M., Pravda A. O. The results of using Holstein bulls for service in breeding a highly productive herd

The purpose of the article is to evaluate the manifestation of economically useful signs of cow-daughters of Holstein breed different servicing bulls.

Methods of the research. In the course of the study, commonly used zoo-technical methods (individual accounting of milk productivity, reproductive capacity), laboratory (determining the qualitative milk composition), retrospective analysis (indicators for the entire period of using animals), variation-statistical method (determining sign parameters) were used.

The research results. As a result of using bulls for service of Holstein breed in creating a highly productive herd of dairy cattle it has been established that the level of developing productive, reproductive and adaptive properties of cow-daughters is influenced by the origin of the father-parent. The correlation has been established between economically useful signs of cows-firstlings of the Holstein breed of German and Ukrainian selection from various bulls. Regardless of the experimental animals' origin, there is a high-level positive correlation between the milk yield and the amount of milk fat and protein. The common peculiarity for the offspring of the Holstein breed is the presence of a positive correlation of the low, middle and high levels between the milk yield and the duration of the service period. The differences as to the direction and the degree of correlation dependence between productive and reproductive features of cows-firstlings have been determined, which characterize the diversity of bulls' influence on their daughters.

The elements of scientific novelty. The theoretical and practical propositions for raising the productivity of animals and creating highly productive herds of dairy cattle by using the gene pool of Holstein breed have been further developed.

Practical significance. The obtained results should be taken into account in the process of improving the selection during the formation of a highly productive herd of the Holstein breed dairy cattle.

Key words: Holstein breed, generations, milk productivity, reproductive capacity, adaptation index, correlation.

Pidpala Tetiana Vasylivna - Doctor of Agricultural Sciences, Professor, Head of the Department of Technology of Processing, Standardization and Certification of Livestock Products, Faculty of Technology of Producing and Processing of Livestock Products, Standardization and Biotechnology, Mykolaiv National Agrarian University, 9, G. Gongadze st., Mykolaiv, 54020, e-mail: pidpala@mnau.edu.ua, ORCID ID: 00000002-4072-7576.

Zaitsev Yevhen Mykolaiovych - Ph.D. degree applicant of higher education of the Department of Technology of Processing, Standardization and Certification of Livestock Products, Faculty of Technology of Producing and Processing of Livestock Products, Standardization and Biotechnology, Mykolaiv National Agrarian University, 9, G. Gongadze st., Mykolaiv, 54020, Ukraine, e-mail: zaitsev_yevhen@ukr.net, ORCID ID: 0000-0002-4165-4196. 


\section{СІЛЬСЬКЕ ГОСПОДАРСТВО. ТВАРИННИЦТВО}

Pravda Anastasiia Oleksandrivna - Master-course student, the Department of Technology of Processing, Standardization and Certification of Livestock Products, Faculty of Technology of Producing and Processing of Livestock Products, Standardization and Biotechnology, Mykolaiv National Agrarian University, 9, G. Gongadze st., Mykolaiv, 54020, Ukraine, e-mail: pravdanasta3@gmail.com.

Стаття надійшла до редакції 02.03.2019 р.

Бібліографічний опис для цитування :

Підпала T. В., Зайщев $C$. М., Правда А. О. Результати використання бугаїв-плідників голштинської породи при створенні високопродуктивного стада. Вісник ПДАА. 2019. № 1. С. 169-180.

DOI 10.31210/visnyk2019.01.19

(C) Підпала Тетяна Василівна, Зайщев Свген Миколайович, Правда Анастасія Олександрівна, 2019 